\title{
ORIGINAL
}

ARTICLES

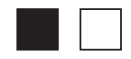

\section{Redesigning Residency Training: Summary Findings From the Preparing the Personal Physician for Practice (P4) Project}

Patricia A. Carney, PhD; M. Patrice Eiff, MD; Elaine Waller; Samuel M. Jones, MD; Larry A. Green, MD

\begin{abstract}
BACKGROUND AND OBJECTIVES: The Preparing the Personal Physician for Practice (P4) project (2007 to 2014) involved a comparative case study of experiments conducted by 14 selected family medicine programs designed to evaluate new models of residency education that aligned with the patient-centered medical home (PCMH). Changes in length, structure, content, and location of training were studied.
\end{abstract}

METHODS: We conducted both a critical review of P4 published Evaluation Center and site-specific papers and a qualitative narrative analysis of process reports compiled throughout the project. We mapped key findings from P4 to results obtained from a survey of program directors on their top 10 "need to know" areas in family medicine education.

RESULTS: Collectively, $\mathbf{8 3 0}$ unique residents took part in P4, which explored $\mathbf{8 0}$ hypotheses regarding 44 innovations. To date, 39 papers have resulted from P4 work, with the P4 Evaluation Center producing 17 manuscripts and faculty at individual sites producing 22 manuscripts. P4 investigators delivered 21 presentations and faculty from P4 participating programs delivered 133 presentations at national meetings. For brevity, we present findings derived from the analyses of project findings according to the following categories: (1) how residency training aligned with PCMH; (2) educational redesign and assessment; (3) methods of financing new residency experiences; (4) length of training; (5) scope of practice; and (6) setting standards for conducting multisite educational research.

CONCLUSIONS: The P4 project was a successful model for multisite graduate medical education research. Insights gained from the P4 project could help family medicine educators with future residency program redesign.

(Fam Med. 2018;50(7):503-17.)

doi: 10.22454/FamMed.2018.829131

n 2004, the Future of Family Medicine Report called for changes in family medicine training and practice aimed at improving the health of the American public. ${ }^{1}$ The Preparing the Personal Physician for Practice (P4) initiative was subsequently undertaken to catalyze innovation in family medicine residency training. ${ }^{2}$ Green et al published an overview article about the project in 2007 that identified 10 "need to know" categories derived from a survey of members of the Association of Family Medicine Residency Directors (AFMRD). ${ }^{2}$ These included: (1) how the residency experience can better align with the Patient-Centered Medical Home (PCMH); (2) how residents can learn to work effectively in teams; (3) how residents can learn to use technology to measure and improve health care quality and patient outcomes; (4) what evidence can support particular experiences determined to be effective in producing skilled personal physicians; (5) what teaching methods appear most effective; (6) what educational outcome measures are meaningful; (7) how best to assess and ensure competency; (8) how to incorporate evidence-based medicine (EBM) into daily clinical practice; (9) how to finance new residency experiences; and (10) how to help graduates adapt to emerging health care system changes. In addition, as part of the P4 implementation and evaluation processes, other areas of study emerged, especially related to the challenges of implementation, which could help residency faculty with their redesign efforts.

The purpose of this study is to outline key findings from $\mathrm{P} 4$, derived both from published papers that address the 10 program directors' "need to know" categories, and the evaluation team's longitudinal observations. These findings could guide other residency educators who are leading change in graduate medical education.

From the Oregon Health and Science University, Portland, OR (Drs Carney and Eiff, and Ms Waller); Virginia Commonwealth University-Fairfax Residency Program, Fairfax, VA (Dr Jones); and University of Colorado (Dr Green). 


\section{Methods}

Background

The 14 P4 programs (Table 1) were selected from 84 initial applications submitted in response to a call for proposals provided to all family medicine residencies followed by a blinded peer-review process for 44 full applications that were invited by the internal review committee. Selection criteria included the novelty of proposed innovations, ability to transform training and practices in alignment with the PCMH features, evaluation capacity, and sustainability and financial viability of proposed innovations. The programs chosen were diverse in size, location, setting (urban and rural), and affiliation (community-based and university-based). The P4 programs formed a comparative case study of experiments involving innovations in residency education that aligned with the PCMH and that included changes in the length, structure, content, and location of training and expanded measurements of competency.

The P4 project, which ran from 2007 to 2014 , was overseen by a steering committee of educators and practicing family physicians. Five inperson learning collaboratives occurred during the project, and site visits that included tailored faculty development sessions were conducted at all sites in the beginning of the project. All participating programs were required to undertake core data collection activities, which included annual surveys completed by residents, program directors, medical directors, and/or clinic staff at continuity clinics. In addition, residency graduates were surveyed 18 months after graduation. All programs and the Evaluation Center, located at Oregon Health and Science University (OHSU), underwent IRB review and were granted exemptions or approvals, based on specific evaluation activities.

\section{Analytic Methods}

We conducted a critical review ${ }^{3}$ of P4 published papers that were produced by the Evaluation Center and by participating $\mathrm{P} 4$ residency programs. We mapped key findings from P4 to results obtained from a survey of program directors on what they believed the top 10 "need to know" areas were in family medicine education. $^{2}$

To date, 39 papers have resulted from P4. Investigators at the P4 Evaluation Center produced 17 publications, ${ }^{4-20}$ and faculty at P4 sites produced 22. ${ }^{21-42}$ The Evaluation Center investigators delivered 21 presentations, and faculty from participating programs delivered 133 presentations at national meetings, though we did not include these in our analyses. We also excluded commentaries and letters to the editor from analyses and selected only papers that provided specific measurable evaluations that were either

Table 1: P4 Residency Sites and Program Types

\begin{tabular}{|c|c|}
\hline Residency Program & Program Type \\
\hline Baylor HCHD Family Medicine Residency Program, Houston, TX & University-based, urban setting \\
\hline Cedar Rapids Medical Education Foundation, Cedar Rapids, IA & $\begin{array}{l}\text { Community-based, university-affiliated, suburban } \\
\text { setting }\end{array}$ \\
\hline $\begin{array}{l}\text { Christiana Care Health System Family Medicine Residency } \\
\text { Program, Wilmington, DE }\end{array}$ & $\begin{array}{l}\text { Community-based, university-affiliated, suburban } \\
\text { setting }\end{array}$ \\
\hline $\begin{array}{l}\text { Hendersonville Family Practice Residency Program, } \\
\text { Hendersonville, NC }\end{array}$ & Community-based, university-affiliated. rural setting \\
\hline $\begin{array}{l}\text { John Peter Smith Hospital Family Medicine Residency Program, } \\
\text { Fort Worth, TX }\end{array}$ & Community-based, university-affiliated, urban setting \\
\hline Lehigh Valley Family Medicine Program, Allentown, PA & $\begin{array}{l}\text { Community-based, university-affiliated, suburban } \\
\text { setting }\end{array}$ \\
\hline Loma Linda Family Medicine Residency, Loma Linda, CA & $\begin{array}{l}\text { Community-based, university-administered, suburban } \\
\text { setting }\end{array}$ \\
\hline $\begin{array}{l}\text { Middlesex Hospital Family Medicine Residency Program, } \\
\text { Middletown, CT }\end{array}$ & $\begin{array}{l}\text { Community-based, university-affiliated, suburban } \\
\text { setting }\end{array}$ \\
\hline Tufts University Family Medicine Residency, Malden, MA & Community-based, university-affiliated, urban setting \\
\hline University of Colorado Family Medicine Residency, Denver, CO & University-based, urban setting \\
\hline $\begin{array}{l}\text { University of Missouri-Columbia Family Medicine Residency, } \\
\text { Columbia, MO }\end{array}$ & University-based, suburban setting \\
\hline $\begin{array}{l}\text { University of Rochester Family Medicine Residency Program, } \\
\text { Rochester, NY }\end{array}$ & $\begin{array}{l}\text { Community-based, university-administered, urban } \\
\text { setting }\end{array}$ \\
\hline Waukesha Family Medicine Residency Program, Waukesha, WI & Community-based, university-affiliated, rural setting \\
\hline $\begin{array}{l}\text { West Virginia University Rural Family Medicine Program, } \\
\text { Harpers Ferry, WV }\end{array}$ & $\begin{array}{l}\text { Community-based, university-administered, rural } \\
\text { setting }\end{array}$ \\
\hline
\end{tabular}


process- or outcomes-based. With these exclusions, we present key findings from 15 (88\%) of the core evaluation papers and 20 (91\%) of the site-specific papers in this critical review. A detailed summary of findings from these publications according to all 10 "need to know" areas is provided in Table 2 for Evaluation Center papers, and in Table 3 for program-specific papers.

To supplement what was published, we conducted a qualitative narrative analysis ${ }^{43}$ of progress reports compiled throughout the project, which involved two members of the evaluation team (MPE and EW) independently reviewing reports for emergent themes using narrative analysis techniques. ${ }^{44}$ These reports provided information from site visits and subsequent program communication, such as telephone conferences and email exchanges, which allowed us to capture the ongoing progress of each innovation implementation and evaluation beyond what was reported in published papers. The documents were organized using a standard report template to ensure consistency and were updated regularly to record process status and challenges. Consensus meetings were used identify emergent themes and exemplars derived from progress reports.

For brevity and to reduce overlap, we present key P4 findings according to six categories that the critical review and the narrative analyses could best address: (1) how residency training aligned with $\mathrm{PCMH},(2)$ educational redesign and assessment, (3) methods of financing new residency experiences, (4) length of training, (5) scope of practice, and (6) setting standards for conducting multisite educational research.

\section{Results}

How Residency Training Aligned With the PCMH

Key Points:

- Simultaneously improving both continuity clinic and resident education operations to incorporate PCMH elements is disruptive to the traditional family medicine clinic model and takes time.

- Team-based care plays a pivotal role in family medicine residency training.

The P4 programs used two approaches to redesign residency training toward the PCMH: (1) focusing on changing the practice then immersing residents into the new environment, or (2) designing specific educational methods and experiences that aligned with the new environment (eg, training residents to lead group visits). Both approaches had success and challenges.

Some PCMH features, such as the electronic health record (EHR), secure remote access, chronic disease registries, and open-access scheduling, were already in place in $2007 .^{5}$ Low areas of implementation included email communication with patients, population-based quality improvement (QI), preventive service registries, and practice-based research using the EHR. Few differences were noted in PCMH features between community-based and university-based programs. ${ }^{5}$ By 2011, P4 programs were primarily successful in implementing EHR-based PCMH features in their continuity clinics. ${ }^{17}$ Notable increases were in email communication with patients $33 \%$ to $67 \%$ ), preventive services registries (63\% to $82 \%$ ), and population-based QI (46\% to $76 \%)$. Team-based care was the only process of care feature associated with a significant upward trend, with a near doubling of this feature over the 5 years of $\mathrm{P} 4$ data collection.

Individual $\mathrm{P} 4$ programs provided more in-depth information on various aspects of PCMH implementation. A low-overhead and high-tech, high-touch approach to patient care was a promising model implemented in one rural community. ${ }^{27}$ One program conducted focus groups to examine the impact of PCMH redesign on residents, faculty, and clinic staff. ${ }^{26}$ Factors associated with success included involving staff in developing solutions, enhancing responsibility, and increasing team cohesion over time. Residents involved in the redesign effort felt that it enhanced their practice experience. Challenges to the process included obtaining sufficient buy-in for the process, ineffective communication from practice leadership, and insufficient staff training. In another P4 program, duty hour restrictions led to decreases in visit numbers, hours spent in clinic, and the number of visits per hour for residents in all years of training. ${ }^{40}$ This 2011 ACGME regulatory change negated the substantial gains this program accomplished in the first 3 years of $\mathrm{P} 4$ toward increasing visit numbers and clinic hours for interns.

Innovations around team-based care were a focus for several P4 programs. ${ }^{4}$ Teamwork and leading teams were identified as core skills for personal physicians in a PCMH. ${ }^{16}$ Increased attention to team-based care in one $\mathrm{P} 4$ program led to better understanding of the role of faculty in role modeling appropriate behaviors and coaching residents about the importance of communication in team huddles. ${ }^{25}$ Ensuring resident attendance during huddles and expecting residents to be part of the team were crucial steps. Another program studied drop-in group medical visits, provided by an interdisciplinary team, and found that emergency department visits dropped by more than half with a corresponding decline in hospital charges for complex patients who had been high utilizers. ${ }^{35}$ Finally, an in-depth study of team-based care found that creating a supportive, safe learning environment for this type of training involves using a different model of professional socialization, and tools for building culture. ${ }^{24}$ Overall, we found that more than $82 \%$ of $\mathrm{P} 4$ graduates reported being adequately trained in teambased care. ${ }^{18}$ Graduates were more than five times more likely to join practices with team-based care in place if well trained in this aspect of clinical care. ${ }^{18}$ 
We found mixed results in the study of resident ratings of the importance of PCMH features based on exposure during training, ${ }^{17}$ and resident satisfaction with training was also variably associated with exposure to PCMH features. ${ }^{15}$ Residents in programs actively changing their practice may have struggled with disruptive forces of innovation, but they still understood and embraced their roles as personal physicians. In analyzing reflections from an online diary system, the majority of resident respondents reported finding meaning in the humanistic and interpersonal aspects of medicine and that being a personal physician in a PCMH meant being the "go-to person for patients' healthcare needs." 16 Interestingly, information technology and registries that facilitate care were not identified as features of personal doctoring.

\section{Educational Redesign and Assessment \\ Key Points:}

- Leadership skills, faculty and staff engagement, and a "learning together" approach were all needed in practices that successfully transformed.

- Innovation attracts more US students to a residency.

- Innovation and regulation can coexist.

- Developing versatile and valid competency assessment measures is time consuming and complex.

P4 definitely helped create a cadre of faculty who catalyzed change to improve training for our future primary care workforce. We identified enablers and barriers to implementation of innovations in our qualitative analysis of progress reports, which are included in Table 4. Our assessment of faculty development needs toward implementing the PCMH indicated that early in P4, faculty needed skills in using and teaching how to use EHR features, change management, curriculum design, evaluation, individualized learning plans, career coaching, competency-based assessment, and leadership. ${ }^{10}$ As the project progressed, a "learning together" approach with residents in transformed practices emerged. Given the pace of change and the evolving nature of the PCMH, faculty partnering with residents to gain new skills was warranted. Additionally, leadership actions important for improving the clinical learning environment while simultaneously transforming resident education included: (1) managing change, (2) developing financial acumen, (3) adapting best evidence educational strategies to the local environment, (4) creating and sustaining a vision that engages stakeholders, and (5) demonstrating courage and resilience. ${ }^{14}$

Early in P4, concerns were raised that disruptive changes might harm student interest and Match performance. In fact, we found the opposite to be true in an analysis of the effect of curricular innovations on residency applications and Match performance. ${ }^{7}$ The mean number of US MD senior applicants per program increased from 53 before $\mathrm{P} 4$ to 81 after P4 implementation, and the mean percent of positions filled in the Match increased from $73 \%$ before P4 to $87 \%$ after P4. Programs that implemented individualized training significantly improved the percent of positions filled in the Match compared to those that did not (90\% vs 83\%). An additional concern was the impact of residency training redesign on residents' clinical knowledge. An analysis by the Evaluation Center revealed that the in-training examination (ITE) scores of $\mathrm{P} 4$ residents were higher compared to national scores in each year, and there was no harm to resident clinical knowledge as a result of curricular changes. ${ }^{19}$

We also examined the extent to which attempting to innovate within the Accreditation Council for Graduate Medical Education (ACGME) regulatory environment influenced the standing of $\mathrm{P} 4$ programs. ${ }^{12}$ The $\mathrm{P} 4$ programs navigated the accreditation process and were able to innovate within the rules without putting their programs at risk. The mean cycle length for all $\mathrm{P} 4$ programs was 4.0 before P4 (2007) and did not change; the average number of citations per program before $\mathrm{P} 4$ was 6.2 , and during $\mathrm{P} 4$ it was 6.8 , with $\mathrm{P} 4$ averages being similar to national norms.

While implementing curricular innovations, the individual $\mathrm{P} 4$ programs also took on the task of studying new measures and methods of accomplishing competency assessment. The site-specific work of one program resulted in (1) a detailed description of a comprehensive, developmentally appropriate competency assessment system ${ }^{31}$ which translated data from checklists of observed behaviors into a "radar graph" useful for both formative and summative assessments ${ }^{37}$; (2) an innovative method of integrating advising and assessment functions to include the voices of resident learn$\mathrm{ers}^{36}$; and (3) new insights about the importance of prompting learners to triangulate feedback from multiple sources when performing self-assessment. ${ }^{41}$ Another program conducted a Delphi process with experts to develop an extensive list of entrustable professional activities (EPAs) for ambulatory practice that provides a roadmap for other programs embarking on competency-based assessment. ${ }^{39}$

\section{Methods of Financing New \\ Residency Experiences \\ Key Point:}

- If committed to making change, you can accomplish it, regardless of the size or resources of your program.

$\mathrm{P} 4$ residency programs only received funding to participate in the collaborative meetings. They did not receive funding from $\mathrm{P} 4$ for their innovations. The lack of programmatic funding was both a strength and weakness. It assured careful decision-making and promoted sustainable strategies under real-world conditions. However, we learned that a clinical operation and a residency cannot be run and innovated 
without some financial help. The P4 programs were successful in their pursuit of additional funds from a variety of sources. Collectively, the six university-based programs received $\$ 5,240,516$ over the study period, compared with $\$ 4,718,943$ received by eight community-based programs. ${ }^{13}$ Most funding came from grants (58\% and $87 \%$, respectively). Training redesign was estimated to add 3\% to budgets for university-based programs and about $2 \%$ to budgets for community-based programs. ${ }^{13}$

\section{Length of Training}

Key Point:

- The optimal length of training in family medicine is still unknown and more study is needed.

P4's evaluation design was a comparative case series, which was not rigorous enough to fully study the impact of length of training on study variables. However, several papers provide new insights about length of training. A report of early outcomes in three $\mathrm{P} 4$ programs, that assessed the impact of longer training required for learner-directed diversification, found that residents in these programs chose a variety of areas of concentration and $40 \%$ of residents chose to extend their residency training to 4 years. ${ }^{32}$ An evaluation of one program that integrated the fourth year of medical school with the first year of residency found that the integrated residents performed significantly better than traditional residents on the ITE during each year of residency training, though no differences were found in patient continuity or panel size. ${ }^{22}$ Additional reports describe curriculum implementation and early outcomes of various 4-year models of training including optional advanced training leading to a degree (eg, MPH) ${ }^{33}$ the nation's first comprehensive required 4-year residency, ${ }^{34}$ and one program with innovative flexible longitudinal tracks. ${ }^{42}$ Overall, the ITE scores of residents in programs that experimented with length of training were similar to those in programs that did not. ${ }^{19}$ Graduates exposed to lengthened training, compared to standard training length, were more likely to include adult hospital care (58\% vs $39 \%)$, adult ICU care (31\% vs $19 \%$ ) and newborn resuscitation ( $26 \%$ vs $14 \%$ ) in their practice and they performed 19 of 30 procedures at higher rates. ${ }^{20}$ More study of the optimal length of training in family medicine is needed and is currently underway. ${ }^{45}$

\section{Scope of Practice}

Key Point:

- Residencies redesigning for our future primary care workforce are still training comprehensive family physicians.

The effect of curricular innovations on the scope of practice of $\mathrm{P} 4$ program graduates was an important outcome measurement in the project. Compared to national data, P4 graduates reported higher rates for vaginal deliveries (19\% vs 9\%), adult inpatient care ( $49 \%$ vs $34 \%$ ) and nursing home care ( $25 \%$ vs $12 \%)$ in practice. ${ }^{20}$ However, this analysis also revealed that $\mathrm{P} 4$ innovations did not significantly change graduate practice scope in the pre- and post$\mathrm{P} 4$ periods. ${ }^{20}$ Thus, the $\mathrm{P} 4$ programs represented a subset of residencies that have historically trained to a broader scope of practice.

Overall, graduates of programs with individualized training innovations reported no significant differences in scope compared to graduates without this innovation. ${ }^{20}$ One $\mathrm{P} 4$ program assessed practice scope of residents who undertook innovative flexible longitudinal tracks, and found that residents who completed a flexible maternal child health track $(n=15)$ compared to all other $\mathrm{P} 4$ graduates $(\mathrm{n}=332)$ were more likely to deliver babies (87\% vs $15 \%)$, perform C-sections as primary surgeon ( $80 \%$ vs $5 \%$ ), care for hospitalized adults ( $87 \%$ vs $44 \%$ ), and care for hospitalized children $(87 \%$ vs $34 \%)^{42}$
Setting Standards for Conducting Multisite Educational Research

Key Points:

- Studying educational effectiveness requires rigorous measures and data collection coupled with educators and researchers working shoulder-to-shoulder to get it right.

- Collaboratives provide support to foster innovation and an evidence-based approach to educational redesign.

- A lack of evaluation expertise in residencies exists.

Establishing meaningful measures at the individual resident, program, clinic, and graduate level are crucial and require rigorous instrument testing, using feasible though high standards for data collection. ${ }^{9}$ Program, continuity clinic, resident, applicant, and Match surveys were collected annually with near 100\% data capture, with a resultant comprehensive relational database of 830 unique residents. The graduate survey response rate was more than $70 \%$ overall for all years (2006 through 2012). ${ }^{20}$ An innovative webbased data viewing portal allowed programs to view their data compared to aggregate data from all 14 programs with annual trend graphs for all measures. The Evaluation Center and the programs partnered in meaningful ways to accomplish this level of data sophistication.

In addition to the development and testing of survey measures used by the P4's Evaluation Center, we also tested and validated a new instrument to measure attributes of family medicine identity in residencies. ${ }^{11}$ This new measure, sensitive enough to detect developmental changes between residents and experienced family medicine faculty, can be used by researchers to study how family medicine identity might develop differently based on various training models or curricular innovations.

All 14 P4 programs participated throughout the 7-year project and met expectations of reporting and collaboration. They proved to 
be an imaginative and courageous group, as well as resilient and persistent innovators. The $\mathrm{P} 4$ programs formed collaboratively, while maturing throughout the project and came to be a force in and of itself. Being a part of this learning community provided additional motivation and structure for getting things done. ${ }^{46}$ Programs supported one another, shared ideas and expertise, collaborated on similar curricular elements, and published and presented together.

Rigorous evaluation in a multiyear, multisite study like $\mathrm{P} 4$ is resource intensive, and programs had little bandwidth and lacked skills to accomplish this. Despite the lack of educational research experience at the start, with guidance from the $\mathrm{P} 4$ evaluation team, all programs were able to develop and refine hypotheses for their innovations and map them to relevant measures. ${ }^{4}$ In total, 38 of $44(86 \%)$ innovations undertaken by the 14 programs were partially or fully implemented, ${ }^{46}$ and programs accomplished partial or full data collection for 63 of 80 (79\%) of the hypotheses they proposed. Many site-specific reports demonstrate that the programs used sophisticated measurement and evaluation designs in their innovation experiments, helping to set high standards for collaborative research.

\section{Discussion}

P4 was successful in many ways. The participating programs all completed the project without being hindered by accreditation and funding issues. P4's achievements can refute the claims that family medicine residencies don't have the time or inclination to take the risks needed to innovate and improve; they do indeed. And we suspect that many of the programs not selected to be in $\mathrm{P} 4(\mathrm{n}=30)$ undertook innovations, even though they were not selected. Thus, it is likely that other non-P4 programs undertook similar innovations that were not measured or tracked by $\mathrm{P} 4$ efforts. Some of these also likely resulted in publication. Importantly, P4 has produced an

Table 2: P4 Evaluation Core Papers' Contributions to Initial "Need to Know" Categories

\begin{tabular}{|c|c|c|}
\hline \multicolumn{3}{|c|}{ Category \#1: How the residency experience can better align with the Patient-Centered Medical Home (PCMH) } \\
\hline $\begin{array}{l}\text { Citation Title } \\
\text { (Reference \#) }\end{array}$ & Key Findings & Conclusions \\
\hline $\begin{array}{l}\text { Aspects of the patient- } \\
\text { centered medical home } \\
\text { currently in place } \\
\text { in community-based } \\
\text { versus academic family } \\
\text { medicine training } \\
\text { programs: Initial findings } \\
\text { from the P4 project (5) }\end{array}$ & $\begin{array}{l}\text { - High areas of implementation }(\geq 50 \%) \text { : having an electronic } \\
\text { health record (EHR), remote access, electronic patient notes/ } \\
\text { scheduling/billing, chronic disease registries, and open-access } \\
\text { scheduling. } \\
\text { - Low areas of implementation }(<50 \%) \text { : asynchronous } \\
\text { communication with patients, population-based QA using } \\
\text { EHR, preventive registries, and practice-based research } \\
\text { using EHR. } \\
\text { - Few differences noted between university- and community- } \\
\text { based residency programs. }\end{array}$ & $\begin{array}{l}\text { Many features of the } \\
\text { PCMH were already } \\
\text { established at baseline in } \\
\text { P4 programs. }\end{array}$ \\
\hline $\begin{array}{l}\text { Assessing the impact of } \\
\text { innovative training of } \\
\text { family physicians for the } \\
\text { patient-centered medical } \\
\text { home (9) }\end{array}$ & $\begin{array}{l}\text { - Nearly } 85 \% \text { of residency continuity clinics were family health } \\
\text { centers, and about } 8 \% \text { were federally qualified health centers. } \\
\text { - Approximately one-half of continuity clinics used the electronic } \\
\text { health record for safety projects, and nearly } 60 \% \text { used it for } \\
\text { quality-improvement projects. } \\
\text { Most P4 residents were non-Hispanic white women }(60.7 \%) \text {, } \\
\text { married or partnered, attended medical school in the United } \\
\text { States and were the first physicians in their families to } \\
\text { attend medical school. }\end{array}$ & $\begin{array}{l}\text { Important baseline } \\
\text { features of residencies } \\
\text { and residents pertinent } \\
\text { to studying the effects of } \\
\text { new training models are } \\
\text { identified. }\end{array}$ \\
\hline $\begin{array}{l}\text { Varied rates of } \\
\text { implementation of } \\
\text { patient-centered medical } \\
\text { home features and } \\
\text { residents' perceptions of } \\
\text { their importance based } \\
\text { on practice experience } \\
\text { (17) }\end{array}$ & $\begin{array}{l}\text { - Implementation of EHR features increased significantly from } \\
2007-2011 \text {, such as email communication with patients (33\% } \\
\text { to } 67 \%) \text {, preventive services registries ( } 23 \% \text { to } 64 \%) \text {, chronic } \\
\text { disease registries }(63 \% \text { to } 82 \%) \text {, and population-based quality } \\
\text { assurance }(46 \% \text { to } 79 \%) \text {. } \\
\text { - Team-based care was the only process of care feature to } \\
\text { change significantly (54\% to } 93 \%) \text {. } \\
\text { - Residents with any exposure to EHR-based features during } \\
\text { training had higher odds of rating the features more } \\
\text { important compared to those with no exposure. } \\
\text { - We observed consistently lower odds of the resident rating } \\
\text { process of care features as more important with any } \\
\text { exposure compared to no exposure. }\end{array}$ & $\begin{array}{l}\text { EHR-based features are } \\
\text { implemented at faster } \\
\text { rates than process of care } \\
\text { features. Exposure to } \\
\text { EHR features positively } \\
\text { influences residents' } \\
\text { importance ratings }\end{array}$ \\
\hline
\end{tabular}


Table 2: Continued

\begin{tabular}{|c|c|c|}
\hline \multicolumn{3}{|c|}{ "Category \#2: How residents can learn to work effectively in teams } \\
\hline $\begin{array}{c}\text { Citation Title } \\
\text { (Reference \#) }\end{array}$ & Key Findings & Conclusions \\
\hline $\begin{array}{l}\text { Team training in family } \\
\text { medicine residency } \\
\text { programs and its impact } \\
\text { on team-based practice } \\
\text { postgraduation (18) }\end{array}$ & $\begin{array}{l}\text { - More than } 82 \% \text { of residency graduates reported being } \\
\text { adequately trained in team-based care. } \\
\text { - Seventy-six percent of P4 graduates joined practices that used } \\
\text { team-based care in } 2011 \text {, which increased to } 86 \% \text { in } 2013 \text {. } \\
\text { - The adjusted odds of practicing in settings with team-based } \\
\text { care was } 5.7 \text { times higher for residents who reported being } \\
\text { adequately prepared for team-based care. }\end{array}$ & $\begin{array}{l}\text { Most residency graduates } \\
\text { reported being well trained } \\
\text { in team-based care, which } \\
\text { is statistically associated } \\
\text { with joining practices } \\
\text { that use team-based care } \\
\text { postgraduation. }\end{array}$ \\
\hline \multicolumn{3}{|c|}{ Category \#3: How residents can learn to more fully use technology to measure and improve quality and outcomes } \\
\hline $\begin{array}{l}\text { Citation Title } \\
\text { (Reference \#) }\end{array}$ & Key Findings & Conclusions \\
\hline $\begin{array}{l}\text { Association between } \\
\text { exposure to features } \\
\text { of the patient-centered } \\
\text { medical home and } \\
\text { satisfaction with family } \\
\text { medicine residency } \\
\text { training in the US. (15) }\end{array}$ & $\begin{array}{l}\text { - Resident satisfaction with training was highest when they } \\
\text { were exposed to using teams to manage care, integrated } \\
\text { case management, and having a credible reliable patient } \\
\text { satisfaction survey but this finding was not sustained over } \\
\text { time. } \\
\text { - Resident satisfaction for many EHR-based features was } \\
\text { significantly lower over the study period. }\end{array}$ & $\begin{array}{l}\text { Resident satisfaction with } \\
\text { training was inconsistently } \\
\text { correlated with exposure to } \\
\text { features of PCMH. }\end{array}$ \\
\hline \multicolumn{3}{|c|}{ Category \#4: What evidence can support particular experiences determined to be effective in producing skilled personal physicians } \\
\hline $\begin{array}{c}\text { Citation Title } \\
\text { (Reference \#) }\end{array}$ & Key Findings & Conclusion \\
\hline $\begin{array}{l}\text { Perceptions of becoming } \\
\text { personal physicians } \\
\text { within a patient-centered } \\
\text { medical home (16) }\end{array}$ & $\begin{array}{l}\text { - Overwhelmingly, resident respondents }(\mathrm{n}=62) \text { reported finding } \\
\text { meaning in the humanistic and interpersonal aspects of } \\
\text { medicine. } \\
\text { - Residents reported that being a personal physician in a PCMH } \\
\text { meant being the "go-to person for patients' healthcare needs." } \\
\text { Being a personal physician included an important role for } \\
\text { the physician and clinical team members in orchestrating the } \\
\text { referral and care coordination process. }\end{array}$ & $\begin{array}{l}\text { Physicians trained } \\
\text { in newly redesigned } \\
\text { residencies understand } \\
\text { their role with patients } \\
\text { and teams that emerge as } \\
\text { part of the PCMH. }\end{array}$ \\
\hline \multicolumn{3}{|c|}{ Category \#5: What teaching methods appear most effective } \\
\hline $\begin{array}{l}\text { Citation Title } \\
\text { (Reference \#) }\end{array}$ & Key Findings & Conclusion \\
\hline $\begin{array}{l}\text { Faculty development } \\
\text { needs in residency } \\
\text { redesign towards the } \\
\text { patient-centered medical } \\
\text { home: a P4 report (10) }\end{array}$ & $\begin{array}{l}\text { - A "learning together" approach when training residents in } \\
\text { transformed practices emerged. } \\
\text { - Using the EHR more effectively, evaluation and competency- } \\
\text { based assessment skills, individualized curriculum design, } \\
\text { career coaching skills, shared leadership, and team-based } \\
\text { care skills were consistent faculty development needs. } \\
\text { - Redesign strategies included having a committed core } \\
\text { faculty group, faculty retreats, curricular change process } \\
\text { management, intra-residency collaboration, and providing } \\
\text { adequate support for key individuals. }\end{array}$ & $\begin{array}{l}\text { Faculty redesigning } \\
\text { residencies to train } \\
\text { residents in the PCMH } \\
\text { need new skills, and } \\
\text { understanding these } \\
\text { needs can inform faculty } \\
\text { development programs } \\
\text { nationally. }\end{array}$ \\
\hline \multicolumn{3}{|c|}{ Category \#6: What educational outcome measures are meaningful } \\
\hline $\begin{array}{l}\text { Citation Title } \\
\text { (Reference \#) }\end{array}$ & Key Findings & Conclusion \\
\hline $\begin{array}{l}\text { A model for a } \\
\text { standardized national } \\
\text { family medicine graduate } \\
\text { survey (6) }\end{array}$ & $\begin{array}{l}\text { Categories of variables common to the graduate surveys of the P4 } \\
\text { programs included physician and practice characteristics, work } \\
\text { load, scope of practice, career satisfaction, and assessment of } \\
\text { training. } \\
\text { Programs varied in the number of procedures and residency } \\
\text { content areas listed on any individual program survey, with the } \\
\text { number of procedure ranging from } 0--21 \text {, and the number of } \\
\text { content areas ranging from } 0-61 \text {. }\end{array}$ & $\begin{array}{l}\text { Using a standardized } \\
\text { national survey provides } \\
\text { important information } \\
\text { about national practice } \\
\text { characteristics and scope } \\
\text { of practice in family } \\
\text { medicine. }\end{array}$ \\
\hline
\end{tabular}


Table 2: Continued

\begin{tabular}{|c|c|c|}
\hline \multicolumn{3}{|c|}{ Category \#6: What educational outcome measures are meaningful } \\
\hline $\begin{array}{l}\text { Citation Title } \\
\text { (Reference \#) }\end{array}$ & Key Findings & Conclusion \\
\hline $\begin{array}{l}\text { Impact of residency } \\
\text { training redesign on } \\
\text { residents' clinical } \\
\text { knowledge (19) }\end{array}$ & $\begin{array}{l}\text { - ITE scores of P4 residents were higher compared to national } \\
\text { - Scores in each year. } \\
\text { - Scores of residents in programs that experimented with length } \\
\text { of training were similar to those in programs that did not. } \\
\text { - Scores were also similar between residents in programs with } \\
\text { and without individualized education options. }\end{array}$ & $\begin{array}{l}\text { FM residency programs } \\
\text { undergoing substantial } \\
\text { educational change did } \\
\text { not appear to negatively } \\
\text { affect residents' clinical } \\
\text { knowledge. }\end{array}$ \\
\hline \multicolumn{3}{|c|}{ Category \#7: How best to assess and ensure competency } \\
\hline & Key Findings & Conclusion \\
\hline $\begin{array}{l}\text { No Evaluation Center } \\
\text { papers in this category }\end{array}$ & See Table 3. & N/A \\
\hline \multicolumn{3}{|c|}{ Category \#8: How to incorporate EBM into daily clinical practice } \\
\hline & Key Findings & Conclusion \\
\hline $\begin{array}{l}\text { No Evaluation Center } \\
\text { papers in this category }\end{array}$ & See Table 3. & N/A \\
\hline \multicolumn{3}{|c|}{ Category \#9: How to finance new residency experiences } \\
\hline $\begin{array}{l}\text { Citation Title } \\
\text { (Reference \#) }\end{array}$ & Key Findings & Conclusion \\
\hline $\begin{array}{l}\text { Financing residency } \\
\text { training redesign (13) }\end{array}$ & $\begin{array}{l}\text { - Most funding came from grants and average revenue (all years } \\
\text { combined) per program for university-based programs was } \\
\text { just under } \$ 875,000 \text { and nearly } \$ 590,000 \text { for community } \\
\text { programs. } \\
\text { - } \\
\text { Majority of funds were dedicated to salary support. Training } \\
\text { redesign added } 3 \% \text { to budgets for university-based programs } \\
\text { and about } 2 \% \text { to budgets for community-based programs. }\end{array}$ & $\begin{array}{l}\text { Residencies undergoing } \\
\text { training redesign used } \\
\text { a variety of approaches } \\
\text { to fund their changes. } \\
\text { The costs of innovations } \\
\text { marginally increased the } \\
\text { estimated costs of training. }\end{array}$ \\
\hline \multicolumn{3}{|c|}{ Category \#10: How to help graduates adapt to changing health care systems } \\
\hline $\begin{array}{l}\text { Citation Title } \\
\text { (Reference \#) }\end{array}$ & Key Findings & Conclusion \\
\hline $\begin{array}{l}\text { Scope of practice among } \\
\text { recent family medicine } \\
\text { residency graduates }(20)\end{array}$ & $\begin{array}{l}\text { - Compared to national data, P4 graduates reported higher } \\
\text { rates for vaginal deliveries (19\% vs } 9 \%) \text {, adult inpatient } \\
\text { care (49\% vs 34\%) and nursing home care (25\% vs } 12 \%) \text { in } \\
\text { practice. } \\
\text { - Graduates exposed to lengthened training, compared to } \\
\text { standard training length, were more likely to include adult } \\
\text { hospital care (58\% vs 39\%), adult ICU care (31\% vs } 19 \%) \text { and } \\
\text { newborn resuscitation (26\% vs } 14 \%) \text { in their practice and } \\
\text { they performed 19/30 procedures at higher rates. } \\
\text { - Graduates of programs with individualized training } \\
\text { innovations reported no significant differences in scope } \\
\text { compared to graduates without this innovation. }\end{array}$ & $\begin{array}{l}\text { Graduates of residencies } \\
\text { engaged in significant } \\
\text { educational redesign } \\
\text { report a broad scope of } \\
\text { practice. Innovations } \\
\text { around the length of } \\
\text { training may broaden } \\
\text { scope and individualized } \\
\text { education appears not to } \\
\text { constrict scope. }\end{array}$ \\
\hline \multicolumn{3}{|c|}{ Other: Residency Redesign Process } \\
\hline $\begin{array}{l}\text { Citation Title } \\
\text { (Reference \#) }\end{array}$ & Key Findings & Conclusion \\
\hline $\begin{array}{l}\text { Effect of curriculum } \\
\text { innovation on residency } \\
\text { applications and match } \\
\text { performance: A P4 report } \\
\text { (7) }\end{array}$ & $\begin{array}{l}\text { - The mean number of US MD senior applicants per program } \\
\text { increased from } 53 \text { before P4 to } 81 \text { after P4 implementation. } \\
\text { - The mean number of applicants interviewed per program } \\
\text { increased nearly } 40 \% \text { in the post-P4 period. } \\
\text { - The mean percent of positions filled in the Match increased } \\
\text { from } 73 \% \text { before P4 to } 87 \% \text { post-P4. }\end{array}$ & $\begin{array}{l}\text { Innovations in residency } \\
\text { curriculum appear to } \\
\text { have a positive influence } \\
\text { on student interest and } \\
\text { program performance in } \\
\text { the Match. }\end{array}$ \\
\hline
\end{tabular}


Table 2: Continued

\begin{tabular}{|c|c|c|}
\hline \multicolumn{3}{|c|}{ Other: Residency Redesign Process } \\
\hline $\begin{array}{l}\text { Citation Title } \\
\text { (Reference \#) }\end{array}$ & Key Findings & Conclusion \\
\hline $\begin{array}{l}\text { Effect of curriculum } \\
\text { innovation on residency } \\
\text { applications and match } \\
\text { performance: A P4 report } \\
\text { (7) }\end{array}$ & $\begin{array}{l}\text { - The mean number of US MD senior applicants per program } \\
\text { increased from } 53 \text { before P4 to } 81 \text { after P4 implementation. } \\
\text { - The mean number of applicants interviewed per program } \\
\text { increased nearly } 40 \% \text { in the post-P4 period. } \\
\text { - The mean percent of positions filled in the Match increased } \\
\text { from } 73 \% \text { before P4 to } 87 \% \text { post-P4. }\end{array}$ & $\begin{array}{l}\text { Innovations in residency } \\
\text { curriculum appear to } \\
\text { have a positive influence } \\
\text { on student interest and } \\
\text { program performance in } \\
\text { the Match. }\end{array}$ \\
\hline $\begin{array}{l}\text { Innovating within the } \\
\text { ACGME regulatory } \\
\text { environment is not an } \\
\text { oxymoron (12) }\end{array}$ & $\begin{array}{l}\text { - Mean cycle length for all P4 programs was } 4.0 \text { before P4 } \\
\text { (2007) and did not change during } \mathrm{P} 4 \text {. } \\
\text { - Average number of citations per program before P4 was } 6.2 \text {, } \\
\text { and during } \mathrm{P} 4 \text { was } 6.8 \text {. } \\
\text { - The P4 averages were similar to national norms during the } \\
\text { project period. }\end{array}$ & $\begin{array}{l}\text { Innovation and redesign } \\
\text { of residency training in } \\
\text { the P4 programs appears } \\
\text { not to have affected the } \\
\text { average cycle length or } \\
\text { number of citations per } \\
\text { program. }\end{array}$ \\
\hline $\begin{array}{l}\text { Five key leadership } \\
\text { actions needed to } \\
\text { redesign family medicine } \\
\text { residencies (14) }\end{array}$ & $\begin{array}{l}\text { - Five leadership actions associated with successful } \\
\text { implementation of innovations and residency transformation: } \\
\text { (1) manage change, (2) develop financial acumen, (3) } \\
\text { adapt best evidence educational strategies to the local } \\
\text { environment,(4) create and sustain a vision that engages } \\
\text { stakeholders, and (5) demonstrate courage and resilience. }\end{array}$ & $\begin{array}{l}\text { Insights about effective } \\
\text { leadership skills can } \\
\text { provide guidance for } \\
\text { faculty to help guide } \\
\text { transformation. }\end{array}$ \\
\hline
\end{tabular}

Table 3: P4 Site-Specific Papers' Contributions to Initial "Need to Know" Categories

\begin{tabular}{|c|c|c|}
\hline \multicolumn{3}{|c|}{ Category \#1: How the residency experience can better align with the Patient-Centered Medical Home (PCMH) } \\
\hline Citation Title (Reference \#) & Key Findings & Conclusion \\
\hline $\begin{array}{l}\text { The effects of residency } \\
\text { practice redesign on } \\
\text { providers and staff (26) }\end{array}$ & $\begin{array}{l}\text { - Focus groups conducted with residents, faculty, and medical } \\
\text { support staff were done to determine factors contributing to } \\
\text { success of a practice redesign experiment. } \\
\text { - Challenges included obtaining sufficient buy-in for the process, } \\
\text { ineffective communication from practice leadership, and } \\
\text { insufficient staff training. } \\
\text { - Facilitating factors included involving staff in developing } \\
\text { solutions, enhanced responsibility, and team cohesion over } \\
\text { time. Residents involved in the redesign effort felt that it } \\
\text { enhanced their practice experience. }\end{array}$ & $\begin{array}{l}\text { Committed leadership } \\
\text { and planning, with } \\
\text { attention to the impact } \\
\text { that redesign will have on } \\
\text { those involved, can greatly } \\
\text { impact the likelihood of } \\
\text { success. }\end{array}$ \\
\hline $\begin{array}{l}\text { Redesigning the Rural } \\
\text { Health Center: high } \\
\text { tech, high touch, and low } \\
\text { overhead (27) }\end{array}$ & $\begin{array}{l}\text { - Most patients }(70 \%) \text { make their appointment within } 24 \text { hours } \\
\text { of their desired visit; } 15 \% \text { walk in without an appointment. } \\
\text { - Working self-paying patients preferred a direct, face-to-face } \\
\text { visit, even though it was significantly more expensive }(\$ 55) \\
\text { than using e-visits ( } \$ 25) \text { or telephone consults }(\$ 35 / 10-\text { minute } \\
\text { consult). } \\
\text { - E-visits were used mostly for routine follow-up care and almost } \\
\text { exclusively by self-paying patients. }\end{array}$ & $\begin{array}{l}\text { PCMH can be successfully } \\
\text { applied to a low-overhead } \\
\text { practice model and may } \\
\text { be ideally suited to rural } \\
\text { or targeted isolated } \\
\text { communities. }\end{array}$ \\
\hline $\begin{array}{l}\text { Resident duty hour } \\
\text { changes: Impact in the } \\
\text { patient-centered medical } \\
\text { home (40) }\end{array}$ & $\begin{array}{l}\text { - PCMH hours and visit numbers were collected and analyzed } \\
\text { for residents in a university-based program from July 2005- } \\
\text { June 2012. } \\
\text { - Comparing the } 2 \text { years before P4 to the first } 3 \text { years after P4 } \\
\text { changes, first-year residents had a } 27 \% \text { increase in patient } \\
\text { visits and } 13 \% \text { increase in hours. } \\
\text { - Following new ACGME regulations, first-year residents } \\
\text { experienced a 33\% decrease in visits with a } 25 \% \text { decrease } \\
\text { in hours negating P4 changes and residents in all years } \\
\text { experienced less visits, less hours, and less visits per hour }\end{array}$ & $\begin{array}{l}\text { New duty hour } \\
\text { regulations limit time } \\
\text { residents spend in } \\
\text { hospitals and ambulatory } \\
\text { settings. Considering } \\
\text { the emphasis family } \\
\text { medicine residencies } \\
\text { place on continuity of } \\
\text { care, regulations will have } \\
\text { implications for these } \\
\text { programs. }\end{array}$ \\
\hline
\end{tabular}


Table 3: Continued

\begin{tabular}{|c|c|c|}
\hline \multicolumn{3}{|c|}{ Category \#2: How residents can learn to work effectively in teams } \\
\hline Citation Title (Reference \#) & Key Findings & Conclusion \\
\hline $\begin{array}{l}\text { Creating collaborative } \\
\text { learning environments } \\
\text { for transforming primary } \\
\text { care practices now }(24)\end{array}$ & $\begin{array}{l}\text { - Developing collaborative, cross-disciplinary teams may be } \\
\text { essential for the success of the PCMH. } \\
\text { - Optimal conditions for collaborative training begins with } \\
\text { delineating types of teams and how they relate to levels of } \\
\text { collaboration. } \\
\text { - Creating a supportive, safe learning environment for this type } \\
\text { of training, involves using a different model of professional } \\
\text { socialization, and tools for building culture. }\end{array}$ & $\begin{array}{l}\text { Implementing } \\
\text { collaborative training } \\
\text { programs for existing } \\
\text { professionals are possible } \\
\text { using competency-based } \\
\text { and adult learning } \\
\text { approaches. }\end{array}$ \\
\hline $\begin{array}{l}\text { Team huddles: the role } \\
\text { of the primary care } \\
\text { educator ( } 25)\end{array}$ & $\begin{array}{l}\text { - Team huddles should include everyone who has contact with } \\
\text { patients during an office session. } \\
\text { - Communication should focus on patient care issues } \\
\text { (anticipated needs, administrative issues, financial/billing } \\
\text { issues)). } \\
\text { - Expect trainee attendance and coach during the huddles. } \\
\text { - Develop huddle champions prior to administration. }\end{array}$ & $\begin{array}{l}\text { Promoting and teaching } \\
\text { the team huddle to } \\
\text { medical trainees will have } \\
\text { far-reaching effects on } \\
\text { the quality of teamwork } \\
\text { and interdisciplinary } \\
\text { communication in medical } \\
\text { settings. }\end{array}$ \\
\hline $\begin{array}{l}\text { Assessing teamwork: } \\
\text { A reliable five-question } \\
\text { survey (30) }\end{array}$ & $\begin{array}{l}\text { - They administered } 29 \text { questions about teamwork from the } \\
\text { Practice Environment Checklist (PEC) to all members of six } \\
\text { clinical teams in a residency outpatient practice }(\mathrm{n}=56) \text {. } \\
\text { - A five item survey assessing a single dimension of teamwork } \\
\text { had acceptable reliability (Cronbach alpha=0.89) and was } \\
\text { completed in less than } 3 \text { minutes. }\end{array}$ & $\begin{array}{l}\text { The resulting short form } \\
\text { of the PEC may be useful } \\
\text { for frequent assessment of } \\
\text { team function. }\end{array}$ \\
\hline $\begin{array}{l}\text { Reducing utilization } \\
\text { by uninsured frequent } \\
\text { users of the emergency } \\
\text { department: combining } \\
\text { case management and } \\
\text { drop-in group medical } \\
\text { appointments (35) }\end{array}$ & $\begin{array}{l}\text { - This study focused on } 255 \text { low-income, uninsured patients who } \\
\text { had used inpatient or ER services more than } 6 \text { times in the } \\
\text { prior } 12 \text { months. } \\
\text { - } 36 \text { patients were enrolled in a twice-weekly drop-in group } \\
\text { medical appointment staffed by an interdisciplinary team } \\
\text { (family physician, behavioral health professional, nurse case } \\
\text { manager). } \\
\text { - The team provided } 705 \text { patient visits in a group setting (a total } \\
\text { of } 108 \text { group sessions) and } 652 \text { case manager phone calls. } \\
\text { - Emergency department use dropped from } 0.58 \text { per patient per } \\
\text { month to } 0.23 \text {, and hospital charges dropped from } \$ 1167 \text { per } \\
\text { patient per month to } \$ 230 \text {. }\end{array}$ & $\begin{array}{l}\text { Team-based drop-in group } \\
\text { medical appointments } \\
\text { coupled with case } \\
\text { management seem to } \\
\text { be a cost-effective model } \\
\text { to reduce emergency } \\
\text { department visits by some } \\
\text { patients with complex } \\
\text { behavioral health and } \\
\text { medical needs. }\end{array}$ \\
\hline \multicolumn{3}{|c|}{ Category \#3: How residents can learn to more fully use technology to measure and improve quality and outcomes } \\
\hline Citation Title (Reference \#) & Key Findings & Conclusion \\
\hline $\begin{array}{l}\text { The role of health } \\
\text { information technology } \\
\text { in creating networks of } \\
\text { medical homes in rural } \\
\text { North Carolina (23) }\end{array}$ & $\begin{array}{l}\text { - A study of EHR implementation in three North Carolina rural } \\
\text { practices resulted in these benefits and challenges: } \\
\text { - The EHR minimizes error-medication refills get done quicker } \\
\text { with fewer mistakes. } \\
\text { - Easier for continuity of care-the medication list is } \\
\text { automatically updated. } \\
\text { - Slow connection to the EHR } \\
\text { - Writing notes takes longer-work day for the providers is } \\
\text { longer than before the EHR was implemented. }\end{array}$ & $\begin{array}{l}\text { The key to achieving } \\
\text { practice efficiencies } \\
\text { using an EHR is its } \\
\text { integrated use to eliminate } \\
\text { unnecessary steps in care } \\
\text { processes that can be done } \\
\text { more efficiently in an } \\
\text { electronic environment. }\end{array}$ \\
\hline \multicolumn{3}{|c|}{ Category \#4: What evidence can support particular experiences determined to be effective in producing skilled personal physicians } \\
\hline & Key Findings & Conclusion \\
\hline $\begin{array}{l}\text { No site-specific papers in } \\
\text { this category }\end{array}$ & See Table 2. & N/A \\
\hline
\end{tabular}


Table 3: Continued

\begin{tabular}{|c|c|c|}
\hline \multicolumn{3}{|c|}{ Category \#5: What teaching methods appear most effective } \\
\hline Citation Title (Reference \#) & Key Findings & Conclusion \\
\hline $\begin{array}{l}\text { Incorporating population } \\
\text { medicine into primary } \\
\text { care residency training } \\
(28)\end{array}$ & $\begin{array}{l}\text { - Twenty-six graduates have completed the formally combined } \\
\text { family and preventive medicine residencies. } \\
\text { - All are board certified in family medicine, and } 22 \text { are board } \\
\text { certified in preventive medicine. } \\
\text { - Graduates work in a variety of academic, quality improvement, } \\
\text { community, and international settings and dual training has } \\
\text { been beneficial in job acquisition and satisfaction. }\end{array}$ & $\begin{array}{l}\text { This type of training, or } \\
\text { modifications of it, should } \\
\text { be part of the debate in } \\
\text { primary care residency } \\
\text { redesign. }\end{array}$ \\
\hline $\begin{array}{l}\text { Sleeping at home: A } \\
\text { new model for a hospital } \\
\text { teaching service }(29)\end{array}$ & $\begin{array}{l}\text { - This paper describes a unique adult inpatient teaching service } \\
\text { in a family medicine residency program that integrates } \\
\text { resident teaching with hospitalist care. } \\
\text { - Hospitalists, not residents, serve as the primary workforce in } \\
\text { the hospital. }\end{array}$ & $\begin{array}{l}\text { By uncoupling the } \\
\text { educational experience of } \\
\text { teaching residents how } \\
\text { to care for hospitalized } \\
\text { patients from the service } \\
\text { demands of the hospital, } \\
\text { it is possible to provide } \\
\text { effective inpatient training } \\
\text { and gain clinic time and } \\
\text { comply with duty hour } \\
\text { limits. }\end{array}$ \\
\hline \multicolumn{3}{|c|}{ Category \#6: What educational outcome measures are meaningful } \\
\hline Citation Title (Reference \#) & Key Findings & Conclusion \\
\hline $\begin{array}{l}\text { No site-specific papers in } \\
\text { this category }\end{array}$ & See Table 2. & N/A \\
\hline \multicolumn{3}{|c|}{ Category \#7: How best to assess and ensure competency } \\
\hline Citation Title (Reference \#) & Key Findings & Conclusion \\
\hline $\begin{array}{l}\text { Generating } \\
\text { developmentally } \\
\text { appropriate competency } \\
\text { assessment at a family } \\
\text { medicine residency }(31)\end{array}$ & $\begin{array}{l}\text { - Eight steps guided the development of this assessment system: } \\
\text { (1) Generate residency-specific competencies, (2) Define } \\
\text { residency-specific competencies, (3) Identify principles of } \\
\text { assessment, (4) Compose and analyze narratives of excellence } \\
\text { within each competency, (5) Distill standard statements from } \\
\text { narratives and organize into Dreyfus levels of competence, } \\
\text { (6) Derive observable behaviors from standard statements to } \\
\text { directly correlate behaviors and competency levels, (7) Design } \\
\text { assessment tools (based on observable behaviors) for six } \\
\text { residency learning sites, and (8) Translate assessment tools } \\
\text { for ACGME competencies. }\end{array}$ & $\begin{array}{l}\text { Narrative reflection was } \\
\text { an effective method to tie } \\
\text { observable behaviors to } \\
\text { competencies. The process } \\
\text { was time intensive; } \\
\text { however, we expect } \\
\text { greater confidence in the } \\
\text { program's capacity to } \\
\text { assess training outcomes }\end{array}$ \\
\hline $\begin{array}{l}\text { RAFT (Resident } \\
\text { Assessment Facilitation } \\
\text { Team): Supporting } \\
\text { resident wellbeing } \\
\text { through an integrated } \\
\text { advising and assessment } \\
\text { process (36) }\end{array}$ & $\begin{array}{l}\text { - Resident Assessment Facilitation Team (RAFT) is an } \\
\text { innovative feedback process utilizing small-group dialogue } \\
\text { that replaces the traditional semi-annual, faculty-wide review } \\
\text { of resident performance. The Arizona Integrative Outcome } \\
\text { Scale (AIOS) was used to describe trends in the well-being } \\
\text { of P4 resident cohorts compared to a resident cohort that } \\
\text { started before full implementation of RAFT } \\
\text { - No statistical differences in study groups were found, though } \\
\text { descriptive data suggest a downward trend in the pre-RAFT } \\
\text { group and stable measures of well-being in the post-RAFT } \\
\text { group. }\end{array}$ & $\begin{array}{l}\text { The trend in our pilot } \\
\text { data suggests a stability } \\
\text { of well-being among our } \\
\text { residents that contrasts } \\
\text { with patterns of resident } \\
\text { burnout noted in existing } \\
\text { research. }\end{array}$ \\
\hline $\begin{array}{l}\text { The Radar Graph: the } \\
\text { development of a graphic } \\
\text { tool to demonstrate } \\
\text { resident competency (37) }\end{array}$ & $\begin{array}{l}\text { - The system translates data obtained from checklists of } \\
\text { observed behaviors completed during educational activities, } \\
\text { including direct observation of clinical care, into a graphic } \\
\text { tool (the "radar graph") usable for both formative and } \\
\text { summative assessment. } \\
\text { - Initial data show that the radar graphs have construct validity } \\
\text { and the radar graphs demonstrated resident growth over } \\
\text { time. }\end{array}$ & $\begin{array}{l}\text { This is a promising tool } \\
\text { for resident feedback and } \\
\text { competency assessment. } \\
\text { Further research is needed } \\
\text { to determine full utility of } \\
\text { radar graphs. }\end{array}$ \\
\hline
\end{tabular}


Table 3: Continued

\begin{tabular}{|c|c|c|}
\hline \multicolumn{3}{|c|}{ Category \#7: How best to assess and ensure competency } \\
\hline Citation Title (Reference \#) & Key Findings & Conclusion \\
\hline $\begin{array}{l}\text { Entrustable professional } \\
\text { activities in family } \\
\text { medicine (39) }\end{array}$ & $\begin{array}{l}\text { - Twenty-one experts participated in two rounds of a Delphi } \\
\text { Process to develop a list of } 76 \text { EPAs for ambulatory care that } \\
\text { should be documented by the end of family medicine training. }\end{array}$ & $\begin{array}{l}\text { This list of EPAs can } \\
\text { be used as a starting } \\
\text { point for family medicine } \\
\text { residency programs } \\
\text { interested in moving } \\
\text { toward a competency- } \\
\text { based assessment. }\end{array}$ \\
\hline $\begin{array}{l}\text { Teaching resident self- } \\
\text { assessment through } \\
\text { triangulation of faculty } \\
\text { and patient feedback }(41)\end{array}$ & $\begin{array}{l}\text { - This retrospective case study evaluates the accuracy of senior } \\
\text { residents' self-assessment in relationship-centered care } \\
\text { compared with that of junior residents. The study population } \\
\text { includes the } 34 \text { residents enrolled from AY } 2009-2012 \text {. } \\
\text { - Concordance rate among first-years was } 27 \% \text { and among third- } \\
\text { years was } 60 \% \text {. A discordance analysis found the Patient } \\
\text { score most often deviated from the other } 2 \text { scores, whereas } \\
\text { the Faculty score was never the sole dissenter. }\end{array}$ & $\begin{array}{l}\text { Trend in improved } \\
\text { concordance rates among } \\
\text { senior residents suggests } \\
\text { that prompting learners to } \\
\text { triangulate feedback from } \\
\text { multiple sources can lead } \\
\text { to a shift in perspective } \\
\text { about competency }\end{array}$ \\
\hline \multicolumn{3}{|c|}{ Category \#8: How to incorporate EBM into daily clinical practice } \\
\hline Citation Title (Reference \#) & Key Findings & Conclusion \\
\hline $\begin{array}{l}\text { Ability of an information } \\
\text { mastery curriculum to } \\
\text { improve residents' skills } \\
\text { and attitudes (38) }\end{array}$ & $\begin{array}{l}\text { - The integrated curriculum consisted of intensive instruction } \\
\text { over the course of } 1 \text { month ( } 30 \text { hours), followed by a } \\
\text { longitudinal series of ongoing conferences, integrated into the } \\
\text { teaching of clinical content. } \\
\text { - Modified Fresno Test scores significantly improved from } \\
104 \text { to } 122 . \text { Nine residents }(40 \%) \text { passed the test at the } \\
\text { start of training, increasing to } 17(73 \%) \text { at the end of the } \\
\text { intervention. }\end{array}$ & $\begin{array}{l}\text { A curriculum of } \\
\text { information mastery, } \\
\text { integrated across the } \\
\text { greater curriculum, } \\
\text { improved trainees' } \\
\text { evidence-based medicine } \\
\text { knowledge and skills and } \\
\text { attitude toward using } \\
\text { evidence to inform clinical } \\
\text { decision making. }\end{array}$ \\
\hline \multicolumn{3}{|c|}{ Category \#9: How to finance new residency experiences } \\
\hline & Key Findings & Conclusion \\
\hline $\begin{array}{l}\text { No site-specific papers in } \\
\text { this category }\end{array}$ & See Table 2. & N/A \\
\hline \multicolumn{3}{|c|}{ Category \#10: How to help graduates adapt to changing health care systems } \\
\hline & Key Findings & Conclusion \\
\hline $\begin{array}{l}\text { No site-specific papers in } \\
\text { this category }\end{array}$ & See Table 2. & N/A \\
\hline \multicolumn{3}{|c|}{ Other: Length of Training } \\
\hline Citation Title (Reference \#) & Key Findings & Conclusion \\
\hline $\begin{array}{l}\text { The University of } \\
\text { Missouri Integrated } \\
\text { Residency: evaluating a } \\
\text { four-year curriculum (22) }\end{array}$ & $\begin{array}{l}\text { - This study evaluates a 4-year training model of an integrated } \\
\text { family medicine residency program that overlaps with the } \\
\text { final year of medical school. } \\
\text { - Integrated residents performed significantly better than } \\
\text { traditional residents on ITE at each year of residency } \\
\text { training, with the difference in mean scores decreasing over } \\
\text { time. No evidence of increased patient continuity or panel } \\
\text { size was noted. }\end{array}$ & $\begin{array}{l}\text { This integrated program } \\
\text { offers several benefits } \\
\text { for both the medical } \\
\text { student and the } \\
\text { residency program, and } \\
\text { it is a potential model } \\
\text { for academic residencies } \\
\text { aiming to recruit and } \\
\text { retain a higher percentage } \\
\text { of their own schools' } \\
\text { students. }\end{array}$ \\
\hline
\end{tabular}


Table 3: Continued

\begin{tabular}{|c|c|c|}
\hline \multicolumn{3}{|c|}{ Other: Length of Training } \\
\hline Citation Title (Reference \#) & Key Findings & Conclusion \\
\hline $\begin{array}{l}\text { Learner-directed } \\
\text { intentional } \\
\text { diversification: the } \\
\text { experience of three (P4) } \\
\text { programs }(32)\end{array}$ & $\begin{array}{l}\text { - This paper presents early outcomes of three P4 programs } \\
\text { that allow learner-directed diversification and either allow } \\
\text { or require extra time, up to } 4 \text { years of residency, to complete } \\
\text { these experiences. } \\
\text { - Residents endorse the changes by two measures: they choose } \\
\text { a wide variety of areas of concentration, and a significant } \\
\text { minority ( } 40 \% \text { ) of residents chose to extend their residency } \\
\text { training to } 4 \text { years, a proportion that grew significantly from } \\
2006 \text { to } 2008 \text {. }\end{array}$ & $\begin{array}{l}\text { Residents willingly } \\
\text { diversified their training } \\
\text { to develop areas of } \\
\text { concentration and a } \\
\text { growing number of them } \\
\text { chose to extend their } \\
\text { training to } 4 \text { years to } \\
\text { attain additional skills. }\end{array}$ \\
\hline $\begin{array}{l}\text { Implementing radical } \\
\text { curriculum change } \\
\text { in a family medicine } \\
\text { residency: the Majors and } \\
\text { Masteries Program (33) }\end{array}$ & $\begin{array}{l}\text { - The Majors and Masteries curriculum begins with } 19 \text { months } \\
\text { of training in core family medicine skills and then residents } \\
\text { elect to pursue a Major or Mastery in an area of interest. } \\
\text { - Majors are completed within } 3 \text { years, while Masteries are } \\
\text { completed in } 4 \text { years and include advanced training (MPH, } \\
\text { MBA, advanced obstetrics). } \\
\text { - Since implementation, residents have selected a broad range } \\
\text { of Majors, three residents have elected advanced training in } \\
\text { three different mastery areas, and resident recruitment has } \\
\text { not been disrupted. }\end{array}$ & $\begin{array}{l}\text { The Majors and Masteries } \\
\text { curriculum and the } \\
\text { process used to implement } \\
\text { it may benefit other } \\
\text { residencies considering } \\
\text { radical curriculum change. }\end{array}$ \\
\hline $\begin{array}{l}\text { Implementation and } \\
\text { preliminary outcomes } \\
\text { of the nation's first } \\
\text { comprehensive 4-year } \\
\text { residency in family } \\
\text { medicine (34) }\end{array}$ & $\begin{array}{l}\text { - The existing 3-year educational core of the program was } \\
\text { left intact, and six additional core rotations and 7-month } \\
\text { tracks of curricular enhancement were added. The residency } \\
\text { practice transformed to a PCMH. } \\
\text { - The funding model was sustainable, and practice income } \\
\text { increased. } \\
\text { - A 4-year curriculum has resulted in substantially increased } \\
\text { applicant interest and improved Match rates. } \\
\text { - The introduction of tracks has appealed to residents and has } \\
\text { generated many positive spin-offs to the educational program } \\
\text { as a whole. }\end{array}$ & $\begin{array}{l}\text { Transition to a } \\
\text { comprehensive } 4 \text {-year } \\
\text { curriculum has been } \\
\text { successful and has } \\
\text { provided many benefits } \\
\text { to our learners, practice, } \\
\text { and educational program. } \\
\text { Our graduates are } \\
\text { substantially better } \\
\text { prepared for practice. }\end{array}$ \\
\hline $\begin{array}{l}\text { Early career outcomes } \\
\text { of family medicine } \\
\text { residency graduates } \\
\text { exposed to innovative } \\
\text { flexible longitudinal } \\
\text { tracks (42) }\end{array}$ & $\begin{array}{l}\text { - Graduates who completed a flexible maternal child health } \\
\text { (MCH) track (n=15) compared to all other P4 graduates } \\
(\mathrm{n}=332) \text { were more likely to deliver babies (87\% vs } 15 \%) \& \\
\text { perform C-sections as primary surgeon }(80 \% \text { vs } 5 \%) \text {. } \\
\text { - Additional areas of expanded scope associated with the MCH } \\
\text { track included endoscopy, care of hospitalized adults and } \\
\text { children, and inpatient procedures. }\end{array}$ & $\begin{array}{l}\text { Graduating from the } \\
\text { MCH track was associated } \\
\text { with a higher provision } \\
\text { of maternal, child, and ill } \\
\text { adult patient care services, } \\
\text { including associated } \\
\text { procedures }\end{array}$ \\
\hline
\end{tabular}

Table 4: Results from Narrative Analysis of Progress Reports: Enablers and Barriers to Implementation of Innovations

\begin{tabular}{|c|c|}
\hline Emergent Themes & Exemplar Statements From Progress Reports \\
\hline \multicolumn{2}{|r|}{ Enablers } \\
\hline $\begin{array}{l}\text { Faculty cohesion and } \\
\text { commitment to project }\end{array}$ & $\begin{array}{l}\text { "Individual faculty members and key staff are each committed to P4 and know their } \\
\text { role and the roles of each other. They communicate with each other regularly about the } \\
\text { project and their tight knit cohesion has allowed them to make the many individual } \\
\text { decisions necessary to keep the implementation moving forward." }\end{array}$ \\
\hline Strong leadership & $\begin{array}{l}\text { "They have leaders who are organized and have the big picture elements as well as the } \\
\text { logistical elements in their sight." }\end{array}$ \\
\hline $\begin{array}{l}\text { Collaboration with other } \\
\text { residencies }\end{array}$ & $\begin{array}{l}\text { "Being part of the bigger P4 initiative to influence the discipline motivated them to go } \\
\text { forward." }\end{array}$ \\
\hline Faculty retreats & They use faculty retreats to slow down and reflect on changes. \\
\hline Faculty and staff involvement & $\begin{array}{l}\text { "Striking a balance between sharing the big picture/project value \& meaning, along with } \\
\text { sharing details \& logistics, helps to keep people engaged and connected." }\end{array}$ \\
\hline
\end{tabular}

(continued on next page) 
Table 4: Continued

\begin{tabular}{|c|c|}
\hline Emergent Themes & Exemplar Statements From Progress Reports \\
\hline \multicolumn{2}{|r|}{ Enablers } \\
\hline $\begin{array}{l}\text { Providing adequate support for } \\
\text { key people }\end{array}$ & $\begin{array}{l}\text { "Having enough faculty who can attend to the business of running a residency supports } \\
\text { faculty who are more involved in the innovation process." }\end{array}$ \\
\hline $\begin{array}{l}\text { Matching curricular } \\
\text { components with faculty } \\
\text { interest }\end{array}$ & "Curricular elements are developed in stages as faculty identify areas of interest." \\
\hline \multicolumn{2}{|r|}{ Barriers } \\
\hline $\begin{array}{l}\text { Lack of on-site analytic } \\
\text { expertise (qualitative and } \\
\text { statistical) and evaluation } \\
\text { resources }\end{array}$ & $\begin{array}{l}\text { "Shifting their precious faculty time resources toward working on evaluation rather } \\
\text { than working on any new competency modules may help, but getting some additional } \\
\text { evaluation support is really what is needed to build some capacity for evaluation." }\end{array}$ \\
\hline Lack of funding & "Funding issues can impact leadership and project coordination." \\
\hline Faculty and staff turnover & $\begin{array}{l}\text { "They are struggling with continuing a project that was conceived and started by faculty } \\
\text { who have since left." }\end{array}$ \\
\hline $\begin{array}{l}\text { Faculty burnout and change } \\
\text { fatigue }\end{array}$ & $\begin{array}{l}\text { "They are in process, stalled somewhere between change and transformation, waiting } \\
\text { for either the environment to change or the significant change fatigue/ burnout (in the } \\
\text { faculty) to pass." }\end{array}$ \\
\hline Uncertainty about change & $\begin{array}{l}\text { "Some faculty expressed reluctance to implement change so quickly, without 'evidence' } \\
\text { that what they've already changed is working." }\end{array}$ \\
\hline
\end{tabular}

extensive body of work with many findings showing improvements in training, results that might not have been possible without the extraordinary data capture we were able to achieve-a feat that is often challenging in educational research.

Now more than ever, training must adapt to emerging advanced practice models that are essential in an efficient and effective health care delivery system. ${ }^{47}$ The lessons learned in $\mathrm{P} 4$ on how best to align residency experiences with the $\mathrm{PCMH}$ and the importance of emphasizing team-based care will help educators produce the kind of residents capable of adapting to, and even leading, needed changes that will undoubtedly occur in the future. To advance such an ambitious agenda, every residency program should become part of a learning collaborative that works together to test and advance educational improvements. Such an approach would enhance residency faculty's abilities to evaluate residents and innovations in training, and achieve goals in scholarly work. It would also contribute to the development of new tools, such as better competency-based medical education assessments. ${ }^{49}$
For example, the graduate survey developed for $\mathrm{P} 4$ contributed to the survey now used by the $\mathrm{ABFM}^{48}$ to assess all family medicine graduates every 3 years, yielding important national outcomes for residencies. Federal GME financing should include economic models to support the development of such "collaboratories," enabled by the American Board of Family Medicine and the Association of Family Medicine Residency Directors.

Inadequate evaluation resources in most residencies and limited funding for educational research has led to curricular changes often being made with little if any evidence to support them. Forming a learning collaborative like the one that occurred in P4 can help drive the graduate medical education research agenda of the future. Such collaboratives engage programs around research questions and appropriate measures, prospectively study how key features change over time, and give programs on-going access to their own data. The power of P4's educational big data to answer educational effectiveness questions should not be overlooked.
The innovations tested by $\mathrm{P} 4$ programs were expected to guide future revisions of family medicine residency requirements. We found evidence that sustaining core skills while flexibly customizing to meet the needs of individual learners did not harm student interest or resident clinical knowledge and scope of practice, and contributed to better understanding of how regulation and innovation can coincide without conflict. The regulatory environment under the current ACGME rules now allows programs that demonstrate high-quality outcomes to gain flexibility to innovate. $^{50}$

In summary, the $\mathrm{P} 4$ project represents a successful change effort for the discipline of family medicine and is an example of a useful model for multisite educational research. The insights gained from the project should help other educators embarking on a path to redesign all family medicine residencies for the future.

ACKNOWLEDGMENTS: This work was supported by the Preparing the Personal Physician for Practice (P4) Project, which was jointly sponsored by the American Board of Family Medicine Foundation, the Association of Family Medicine Residency Directors, and the Family Medicine Research Program at Oregon Health and Science University, Portland, OR. 
CORRESPONDING AUTHOR: Address correspondence to Dr Carney, Professor of Family Medicine, Oregon Health and Science University, 3181 SW Sam Jackson Park Rd MC: FM, Portland, OR 97239. 503-494-9049. Fax: 503-494-2746. carneyp@ohsu.edu.

\section{References}

1. Martin JC, Avant RF, Bowman MA, et al; Future of Family Medicine Project Leadership Committee. The Future of Family Medicine: a collaborative project of the family medicine community. Ann Fam Med. 2004;2(suppl 1):S3S32.

2. Green LA, Jones SM, Fetter G Jr, Pugno PA. Preparing the personal physician for practice: changing family medicine residency training to enable new model practice. Acad Med. 2007;82(12):1220-1227.

3. Grant MJ, Booth A. A typology of reviews: an analysis of 14 review types and associated methodologies. Health Info Libr J. 2009;26(2):91-108.

4. Carney PA, Eiff MP, Green LA, et al. Preparing the personal physician for practice $(\mathrm{P} D)$ : sitespecific innovations, hypotheses, and measures at baseline. Fam Med. 2011;43(7):464-471.

5. Carney PA, Eiff MP, Saultz JW, et al. Aspects of the patient-centered medical home currently in place: initial findings from preparing the personal physician for practice. Fam Med. 2009;41(9):632-639

6. Eiff P, Garvin R, Fogarty CT, et al. A model for a standardized national family medicine graduate survey. Fam Med. 2009;41(5):337-341.

7. Garvin RD, Eiff MP, Pugno P, et al. A P4 report: effect of curriculum innovation on residency applications and match performance. Fam Med. 2011;43(7):472-479.

8. Carney PA, Green LA. An emerging epidemic of innovation in family medicine residencies. Fam Med. 2011;43(7):461-463.

9. Carney PA, Eiff MP, Saultz JW, et al. Assessing the impact of innovative training of family physicians for the patient-centered medical home. J Grad Med Educ. 2012;4(1):16-22.

10. Eiff MP, Waller E, Fogarty CT, et al. Faculty development needs in residency redesign for practice in patient-centered medical homes: a P4 report. Fam Med. 2012;44(6):387-395.

11. Carney PA, Waller E, Eiff MP, et al. Measuring family physician identity: the development of a new instrument. Fam Med. 2013;45(10):708718

12. Eiff MP, Garvin R, Green LA, et al. Innovating within the ACGME regulatory environment is not an oxymoron. Fam Med. 2014;46(4):282287.

13. Carney PA, Waller E, Green LA, et al. Financing residency training redesign. J Grad Med Educ. 2014;6(4):686-693.

14. Kozakowski SM, Eiff MP, Green LA, et al. Five key leadership actions needed to redesign family medicine residencies. J Grad Med Educ. 2015;7(2):187-191

15. Carney PA, Waller E, Dexter E, et al. Association between patient- centered medical home features and satisfaction with family medicine residency training in the US. Fam Med. 2016;48(10):784-794

16. Carney PA, Jacob-Files E, Rosenkranz SJ, Cohen DJ. Perceptions of becoming personal physicians within a patient-centered medical home. J Health Edu Res Dev. 2016;4(3):179184.
17. Eiff MP, Green LA, Jones G, et al. Varied rates of implementation of patient centered medical home features and residents' perceptions of their importance based on practice experience. Fam Med. 2017;49(3):183-192.

18. Carney PA, Waller E, Dexter E, et al. Team training in family medicine residency programs and its impact on team-based practice post-graduation. Fam Med. 2017;49(5):346-352.

19. Waller E, Eiff MP, Dexter E, et al. Impact of residency training redesign on residents' clinical knowledge. Fam Med. 2017;49(9):693-698.

20. Eiff MP, Hollander-Rodriguez J, Skariah J, et al. Scope of practice among recent family medicine residency graduates. Fam Med. 2017;49(8):607-617.

21. Webb AR, Young RA, Casey DF, Baumer JG. Matching up with P4. Fam Med. 2008;40(10):692.

22. Ringdahl E, Kruse RL, Lindbloom EJ, Zweig SC. The University of Missouri integrated residency: evaluating a 4-year curriculum. Fam Med. 2009;41(7):476-480

23. Crane S. The role of health information technology in creating networks of medical homes in rural North Carolina. N C Med J. 2009;70(3):256-259

24. Miller WL, Cohen-Katz J. Creating collaborative learning environments for transforming primary care practices now. Fam Syst Health. 2010;28(4):334-347.

25. Fogarty CT, Schultz S. Team huddles: the role of the primary care educator. Clin Teach. 2010;7(3):157-160.

26. Jones GL, Lima E. The effects of residency practice redesign on providers and staff. Fam Med. 2011;43(7):522-525.

27. Crane S. Redesigning the rural health center high tech, high touch, and low overhead. N C Med J. 2011;72(3):212-215.

28. Dysinger WS, King V, Foster TC, Geffken D. Incorporating population medicine into primary care residency training. Fam Med 2011:43(7):480-486

29. Erlich DR, Shaughnessy AF. Sleeping at home: a new model for a hospital teaching service. $J$ Grad Med Educ. 2011;3(2):243-245

30. Lurie SJ, Schultz SH, Lamanna G. Assessing teamwork: a reliable five-question survey. Fam Med. 2011;43(10):731-734.

31. Baglia J, Foster E, Dostal J, Keister D, Biery N, Larson D. Generating developmentally appropriate competency assessment at a family medicine residency. Fam Med. 2011;43(2):9098.

32. LoPresti L, Young R, Douglass A. Learnerdirected intentional diversification: the experience of three P4 programs. Fam Med. 2011:43(2):114-116

33. Mazzone M, Krasovich S, Fay D, et al. Implementing radical curriculum change in a family medicine residency: the majors and masteries program. Fam Med. 2011;43(7):514-521.

34. Douglass AB, Rosener SE, Stehney MA. Implementation and preliminary outcomes of the nation's first comprehensive 4-year residency in family medicine. Fam Med. 2011;43(7):510513.
35. Crane S, Collins L, Hall J, Rochester D, Patch S. Reducing utilization by uninsured frequent users of the emergency department: combining case management and drop-in group medical appointments. J Am Board Fam Med. 2012;25(2):184-191.

36. Foster E, Biery N, Dostal J, Larson D. RAFT (Resident Assessment Facilitation Team): supporting resident well-being through an integrated advising and assessment process. Fam Med. 2012;44(10):731-734.

37. Keister DM, Larson D, Dostal J, Baglia J. The radar graph: the development of an educational tool to demonstrate resident competency. J Grad Med Educ. 2012;4(2):220-226.

38. Shaughnessy AF, Gupta PS, Erlich DR, Slawson DC. Ability of an information mastery curriculum to improve residents' skills and attitudes. Fam Med. 2012;44(4):259-264.

39. Shaughnessy AF, Sparks J, Cohen-Osher M, Goodell KH, Sawin GL, Gravel J Jr. Entrustable professional activities in family medicine. J Grad Med Educ. 2013;5(1):112-118.

40. Lindbloom EJ, Ringdahl E. Resident duty hour changes: impact in the patient-centered medical home. Fam Med. 2014;46(6):463-466.

41. Keister DM, Hansen SE, Dostal J. Teaching resident self-assessment through triangulation of faculty and patient feedback. Teach Learn Med. 2017;29(1):25-30.

42. Young RA, Casey D, Singer D, Waller E, Carney PA. Early career outcomes of family medicine residency graduates exposed to innovative flexible longitudinal tracks. Fam Med. 2017;49(5):353-360.

43. Camic PM, Rhodes JE, Yardley L. Qualitative Research in Psychology: Expanding Perspectives in Methodology and Design. Washington, DC: American Psychological Association; 2003.

44. Riessman CK. Narrative Methods for the Human Sciences. Los Angeles, CA: SAGE Publications; 2008.

45. Carek PJ. The length of training pilot: does anyone really know what time it takes? Fam Med. 2013;45(3):171-172.

46. Carney PA, Eiff MP, Waller E Jones SA, Green LA. Redesign of Residency Training: Final Results from P4. Presentation at 2013 Annual STFM Meeting. http://www.stfm.org/Conferences/AnnualSpringConference/PastConferences/PastAbstracts,Brochures,Handouts,Vide os/2013STFMAnnualConference $? \mathrm{~m}=6 \& \mathrm{~s}=679$ Accessed July 18, 2017.

47. Gupta R, Dubé K, Bodenheimer T. The road to excellence for primary care resident teaching clinics. Acad Med. 2016;91(4):458-461.

48. Holmboe ES, Sherbino J, Long DM, Swing SR, Frank JR. The role of assessment in competency-based medical education. Med Teach. 2010;32(8):676-682

49. Mitchell KB, Maxwell L, Miller T. The national graduate survey for family medicine. Ann Fam Med 2015;13(6):595-596.

50. Nasca TJ, Philibert I, Brigham T, Flynn TC. The next GME accreditation system--rationale and benefits. N Engl J Med. 2012;366(11):10511056. 